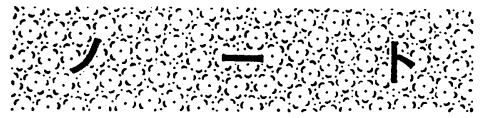

\title{
相間移動触媒による食品中のサッカリンナトリウムの分析法
}

(昭和 55 年 4 月 22 日受理)

高 槻 圭 悟* 堺 敬 一*

\section{Determination of Saccharin in Foods by Methylation with the Aid of a Phase Transfer Catalyst}

\author{
Keigo TAKaTSUKI and Keiichi SAKAI
}

(Miyagi Prefectural Institute of Public Health: 4-7-2, Saiwai-cho, Sendai, Miyagi)

\begin{abstract}
Phase transfer catalysis was utilized for the methylation of saccharin, which was extracted and methylated in one process (extractive methylation). Saccharin in aqueous solution was extracted into an organic solvent as an ion pair with tetrabutylammonium (phase transfer catalyst) and methylated with methyl iodide at room temperature. The resulting $N$-methyl saccharin was quantitated by gas-liquid chromatography on a $5 \% \mathrm{OV}-1$ or 5\% OV-17 column equipped with a flame ionization detector or flame photometric detector (sulfur mode) without any clean-up procedures. Dibenzothiophene was used as an internal standard for both detectors. The peak of $N$-methyl saccharin was well separated and no interfering peak was observed even though no clean-up procedure was used. The mean recovery of added saccharin in soy sauce was $94.2 \%$, with a $5.7 \%$ coefficient of variation. This method offers several advantages, including greater simplicity, rapidity, and a small requirement for organic solvents, over other methods now commonly used, and avoids the use of poisonous substances such as diazomethane. This procedure is applicable to daily routine analysis of saccharin in various liquid foods.
\end{abstract}

(Received April 22, 1980)

\section{1. 序}

サッカリンナトリウムは，各種の食品に使用基準が定 められた1) 合成甘味料として用いられている。この锺量 分析法としては種々の方法が報告されている2゙が，厚生 省通達による食品添加物分析法 ${ }^{3)}$ では, メチル誘導体の ガスクロマトグラフィー（GLC）による定量法が採用さ れている.これは分析精度も比較的良好であり, 機器の 普及度も広く, 最も一般的に使用されていると思われる。 しかしメチル誘導体を得る試薬としてジアン゙メタンを用 いており，これは低沸点で毒性が強く丞発性を有するた め, 取扱いや操作に注意を要し，日常分析の方法として は難点を残していると思われる．このメチル化の段階に

* 宮城県衛生研究所：仙台市幸町 4-7-2
相間移動触媒 ${ }^{4)}$ を利用すれば，抽出とメチル化を同一の 操作で行うため (extractive methylation ${ }^{5)}$ ) 極めて簡 便な分析法になると共に，有機溶媒の使用量む極く少量 ですみ，有毒物質の使用も避けるなどの利点があり，日 常分析の方法として適当であると思われる。そこでメチ ル化の反応条件に検討を加光，妨害物質が多く定量が困 難とされているしょら油を主に清涼领料水などの分析に 適用したところ良好な結果を得ることができたのでこれ を報告する。

\section{2. 実娩方法}

(1) 試 薬

サッカリンナトリウム：食品添加物規格品

臭化テトラ-nーブチルアンモニウム $(\mathrm{TBA})$ : 東京化成 工業(株)製 
ヨウ化メチル：和光純薬工業 (株) 製, 試薬特級 ジベンゾチオフェン：和光純薬工業(株)製, 試薬特級 その他の試薬：試薬特級を使用した。

サッカリンナトリウム標準溶液：サッカリンナトリウ ムを $120^{\circ}$ で 4 時間乾燥後, その $100 \mathrm{mg}$ を水に溶かし て $100 \mathrm{mI}$ とし標準原液 $(1000 \mathrm{ppm})$ とする. これを水 で希釈して各濃度の標準溶液をつくる.

内部標準溶液：ジベンゾチオフェン $100 \mathrm{mg}$ を塩化メ チレンに溶かして $100 \mathrm{ml}$ とし, その $20 \mathrm{ml}$ をとり塩化 メチレンで $100 \mathrm{ml}$ として $200 \mathrm{ppm}$ 溶液とする.この $10 \mathrm{ml}$ をとり塩化メチレンで $100 \mathrm{ml}$ として $20 \mathrm{ppm}$ 溶 液とする，FID の場合には $200 \mathrm{ppm}$ 溶液, FPD の場 合には $20 \mathrm{ppm}$ 溶液を用いる.

相間移動触媒・リン酸塩溶液: $M / 30$ 䟴度のリン酸一 水素ナトリウム水溶液 $100 \mathrm{ml}$ に臭化テトラ-n-ブチルア ンモニウム $0.5 \mathrm{~g}$ を溶解する.

\section{(2) 装 置}

振とう機：ヤヨイ 8-1-W

ガスクロマトグラフ：島津製作所製 GC-7AG， GC4CMPF ・ FPD

\section{(3) 分析操作}

(1) 試験溶液の調製

せん付試験管 $(10 \mathrm{ml}$ ) に試料 $1 \mathrm{ml}$ (サッカリンナトリ ウム含有量: FID の場合 $1.0 \sim 0.1 \mathrm{mg}, \mathrm{FPD}$ の場合 100〜 5 $\mu \mathrm{g})$ をとり，相間移動触媒・リン酸塩溶液 $3 \mathrm{ml}$ を加え混合する.内部標準溶液 $1 \mathrm{ml}$, ヨウ化メチル 100 $\mu 1$ を加え，せんをして振とう㙨を用いて 60 分間振とう する.静置して分離した塩化メチンン層を GLC 用試験 溶液とする。

(2) ガスクロマトグラフィーの条件

カラム管：内径 $3 \mathrm{~mm}$, 長さ $2 \mathrm{~m}$ ，ガラス製

カラム充てん剂：OV-1 (5\% Chromosorb WHP, 80 〜 $100 \mathrm{mesh})$, OV -17 (5\% Chromosorb WHP, 80 $100 \mathrm{mesh}$ )

カラム温度: OV $-1160^{\circ}$; OV $-17180^{\circ}$

試料注入口温度: $270^{\circ}$

キャリアーガス：窒素, 流量 $60 \mathrm{ml} / \mathrm{min}$

感度：FID (GC-7AG) Atten. 16. Range $10^{2}$

FPD (GC-4CM) Sens $10 \mathrm{M} \Omega$

Range $0.16 \sim 1.28 \mathrm{~V}$

\section{(3) 定量法}

サッカリンナトリウム標準溶液について試料と同様の 操作を行い，ピーク高を測定して内部標準法により検量 線を作製する．試験溶液についても同様に操作して得ら れたガスクロマトグラムからピーク高比を求め検量線を 用いて定量する.

\section{3. 結果および考察}

\section{（1）触媒および有機溶媒の選択}

相間移動触媒としては，各種の四級アンモニウム・ホ
スホニウム塩が用いられてきているが，入手が容易であ り，文献の反応例で比較的效率の良いことが確かめられ ている6)テトラ・n-ブチルアンモニウム塩 (TBA) を用い ることにした，有機溶媒は一般にはクロル炭化水素系が 使われており，塩化メチレン，クロロホルム，ジェチル エーテルを試みた結果，塩化メチレンで最も良好な結果 が得られ，これを用いることにした。

\section{（2）メチル化の条件の検討}

以下の条件の検討はサッカリンナリトウム $1 \mathrm{mg}$ (標 準原液 $1 \mathrm{ml}$ ), 水又は緩衝液 $2 \sim 3 \mathrm{ml}$, 有機溶媒塩化メ チレン $1 \mathrm{ml}$ の条件で行った.

(1) ヨウ化メチルの量

ヨウ化メチルの使用量は $10 \mu 1$ では不足し, $50 \mu 1$ で もやや収率が低かったが，100 $\mu 1$ で十分であることが分 った (Fig. 1).この時の再現性も良好であり，100 $\mu 1$ を 使用することにした。

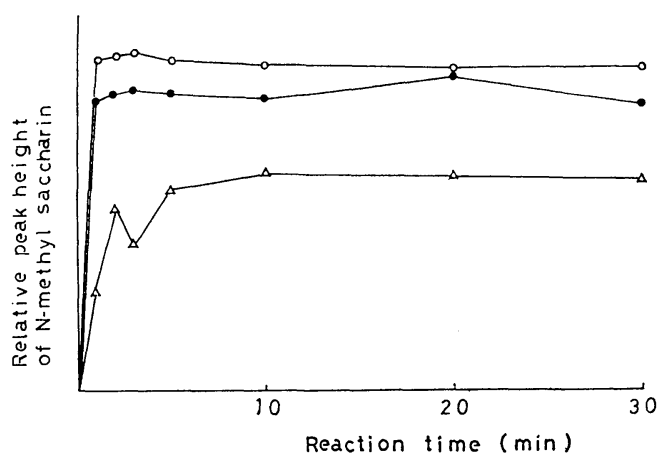

Fig. 1. Effect of amount of methyl iodide for methylation of saccharin $\bigcirc-\mathrm{O}, \mathrm{CH}_{3} \mathrm{I} 100 \mu \mathrm{l}$; $\mu \mathrm{l} ; \triangle \longrightarrow \triangle, \mathrm{CH}_{3} \mathrm{I} 10 \mu \mathrm{l}$

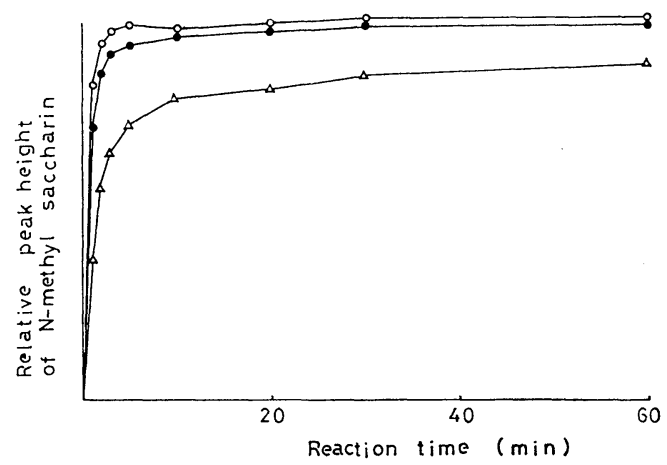

Fig. 2. Effect of concentration of catalyst for methylation of saccharin $(n-\mathrm{Bu})_{4} \mathrm{~N}^{+} \mathrm{Br}^{-}$conc.:

$$
\begin{aligned}
& \bigcirc-O, 0.47 \% \\
& \triangle \longrightarrow \triangle, 0.06 \%
\end{aligned}
$$




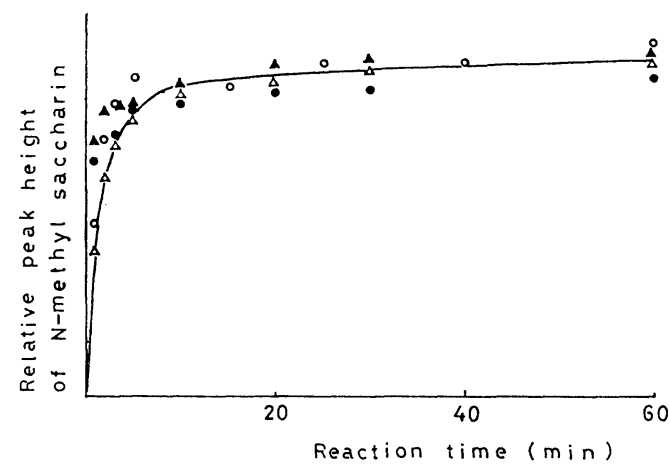

Fig. 3. Effect of $\mathrm{pH}$ of aqueous phase for methylation of saccharin $\bigcirc-\bigcirc, \mathrm{ph} 4.8 ; \triangle \longrightarrow \triangle, \mathrm{pH} \mathrm{7.0}$;
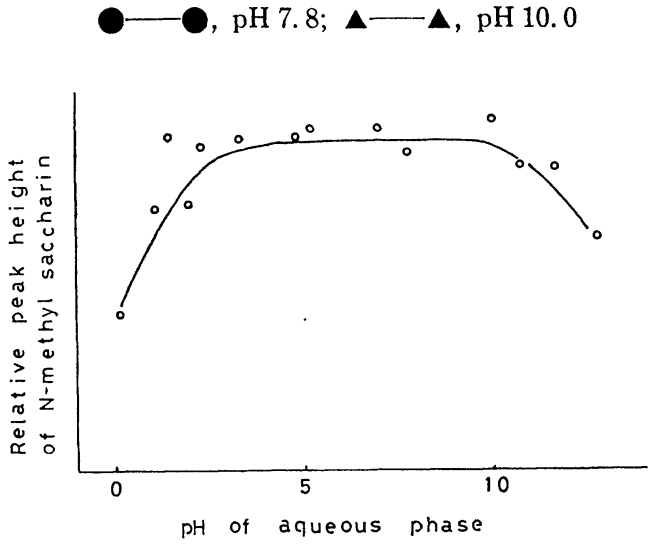

Fig. 4. Effect of $\mathrm{pH}$ of aqueous phase for methylation of saccharin

\section{(2) TBA 濃度}

水層の TBA 濃度は $0.24 \%$ から $0.47 \%$ で定量的に メチル化されることが分った (Fig. 2). 試料に加える相 間移動触媒・リン酸塩溶液の TBA 濃度を $0.5 \%$ とすれ ば，試料と混合したときに $0.375 \%$ となり上記の TBA 濃度範䧃に入るので，この濃度を用いることにした。

(3) 水層の $\mathrm{pH}$

水層の $\mathrm{pH} 5$ から 10 までの間ではメチル化は影響を 受けず定量的であり, 反応速度にも差は見られなかった (Fig. 3). しかしこの範囲を越える強酸性, 強アルカリ性 では，反応時間60分の結果ではメチル誘導体の収率が半 減した (Fig. 4). 強酸性ではサッカリンの解離が抑兄ら れるためであり，強アルカリ下では生成したメチル誘導 体が分解してしまらためと考えられる， $M / 30$ 濃度のリ ン酸一水素ナリトウム溶液 $3 \mathrm{ml}$ を加えることにより, 水層の $\mathrm{pH}$ を約 8 に保ってメチル化を行らことにした。

(4) 反応時間

反応時間は 5〜10 分間でほほ 90\%メチル化される が，更に徐々に反応の進行が見られるので，60分間反応

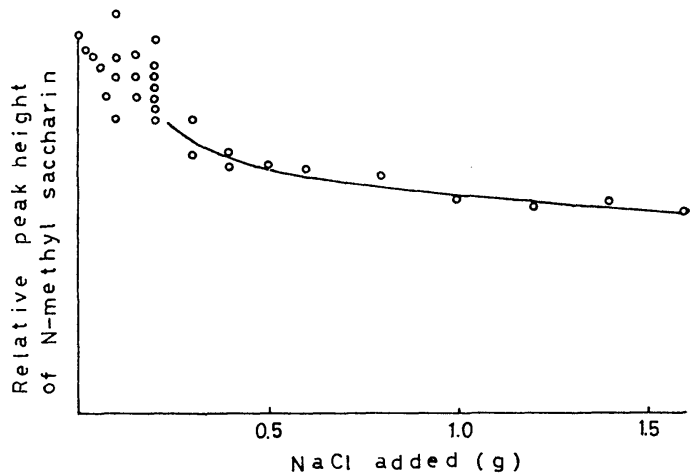

Fig. 5. Effect of sodium chloride for methylation of saccharin

させることにした，反応液はそのまま室温に 1 晚放置し ても変化はみられなかった。

\section{（3）塩化ナトリウムの影響}

大量の塩化ナトリウムの存在はメチル化を妨害し, 塩 化ナトリウム量の増加とともに反応収率が減少するのが みられた (Fig. 5). しかし試料溶液 $1 \mathrm{ml}$ に塩化ナトリ ウムを $0.1 \mathrm{~g}$ 添加した場合のサッカリンナトリウムの回 収率は 90\% 以上であり，0.2 g の添加でも 80 100\% の範囲に入っており,これは試料量 $1 \mathrm{ml}$ 中塩化ナトリ ウム濃度 $20 \%$ に相当し実際の食品の場合には実用上問 題はないと考えられる。

\section{(4) メチル誘導体}

相間移動触媒により生成したメチル誘導体を, ジアゾ メタンにより得られたメチル誘導体とガスクロマトグラ ム上で比較したところ，前者では $N$-メチル誘導体のピ 一クのみ観察されたＮ.メチルおよび O.メチル誘導体 が得られるジアゾメタン法と比較し，N-メチル誘導体 の単一ピークが得られることは, 分析上は都合が良いと 思われる.

\section{（5） ガスクロマトグラフのカラム充てん風}

メチル化反応後の有機層には若干四級アンモニウム塩 が溶解して亦り，これが GLC のカラム中で徐々に熱分 解を起こしていると思われる．FID ではこのため生成 するピークが溶媒ピークに続くテーリングとなってみら れ，DEGS (5\%) を用いたカラムではこれがサッカリン ナトリウムの定量の妨害になるほどはなはだしかった。

しかし OV-1 および OV-17 のカラムを用いれば十分 分離して定量可能であり, FID を使用する場合は OV-1 が最も良好なクロマトグラムを与えた。 なお何らクリー ンアップ操作を加えていないが，しょう油の複雑な成分 に由来する妨害ピークはみられなかった (Fig. 6). また FPD を用いた場合には硫黄に特異的な感度を有するた め, 上述のテーリングもまったくみられず, OV-1, OV17, DEGS のカラムで良好なクロマトグラムを得るこ とができる。 

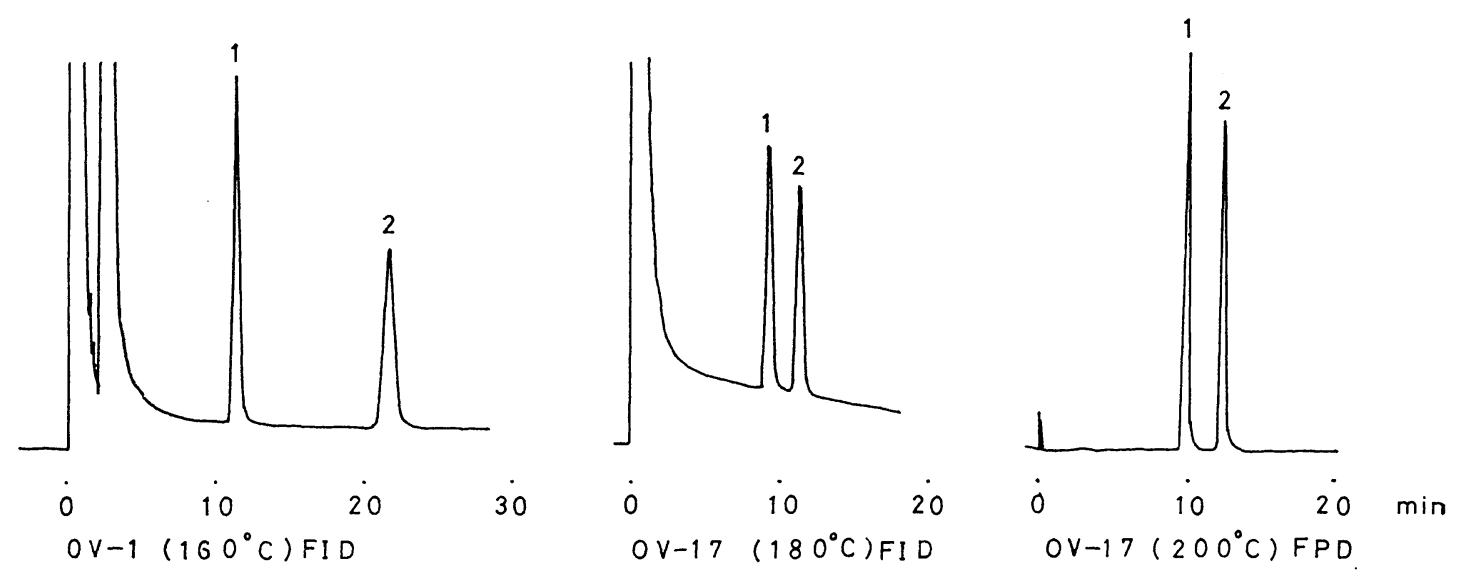

Fig. 6. Gas chromatograms of methylated saccharin sample: soy sauce peak 1, $N$-methyl saccharin; peak 2, internal standard (dibenzothiophene)

\section{(6) 検量線}

検量線は原点を通るほぼ良好な直線が得られた，定量 範囲は FID を用いた場合には試料 $1 \mathrm{ml}$ 中サッカリン ナトリウム $1.0 \sim 0.1 \mathrm{mg}, \mathrm{FPD}$ を用いた場合は 100〜 $5 \mu \mathrm{g}$ である.

\section{(7) 添加回収実験}

サッカリンナトリウム $500 \mathrm{ppm}$ 添加のしょら油を試 料溶液として FID を用いた 10 回の回収実験の結果, 平均回収率 $94.2 \%$, 変動係数 (CV\%) 5.7 であった。 またサッカリンナトリウム $300 \mathrm{ppm}$ 添加の無果汁领料 および $50 \%$ 果汁领料（みかん）についての FIDを用い た回収実験では 3 回の分析の平均率がそれぞれ $99 \%$ お よび 102\% と良好であった。

\section{4. まとめ}

サッカリンナトリウムのメチル化に相間移動触媒を用 いて，抽出とメチル化を一段階の操作で行い分析法をご く簡易化することができた，生成した $N$-メチルサッカ リンは，何らクリーンアップ操作を加えず FID または FPD 付ガスクロマトグラフで定量することができた。 操作が簡単で分析所要時間も短く, 有機溶媒の使用量も 少い等の利点があり，ジアゾメタンの上らな有毒物質の 使用も避けており，日常分析の方法として適していると

\section{思われる。}

なお本研究の要旨は日本食品衛生学会第38回学術講演 会 (1979年11月，仙台）において発表した.

\section{文献}

1）厚生省令第30号（昭和50年 7 月 25日）

2）加藤三郎：食品衛生研究， 24，469～477，543～ 552, 887 903 (1974); Page, B. D., Conacher, H. B. S.: Pure Appl. Chem., 50, 243 254 (1978).

3）厚生省環境衛生局食品化学課：食品中の添加物分 析法, 第 1 集, 昭和 51 年 2 月.

4) Weber, W.P., Gokel, G. W.: 田代岩夫，西谷孝 子訳 “相間移動触媒” (1978) 化学同人.

5) Ehrsson, H., Tilly, A.: Anal. Lett., 6, 197 210 (1973); Ervık, M., Gustavii, K.: Anal. Chem., 46, 39 42 (1974); Gyllenhaal, O., Brötell, H., Sandgren, B.: J. Chromatogr., 122, 471 477 (1976); Gyllenhaal, O., Brötell, H., Hartrig, P.: J. Chromatogr., 129, 295 302 (1976).

6) Herriott, A. W., Picker, D.: J. Am. Chem. Soc., 97, 2345 2349 (1975). 